\title{
Phylogeny and biogeography of midwife toads (Alytes, Discoglossidae): a reappraisal
}

\author{
Cristian R. Altaba \\ Institut Mediterrani d'Estudis Avançats (C.S.I.C.-U.I.B.), Ctra. Valldemossa, Km 7.5, 07071 Palma de \\ Mallorca (Illes Balears, Spain)
}

Keywords: Alytes, midwife toads, taxonomy, phylogeny, biogeography, Western Mediterranean, Iberia, Balearic Islands

\begin{abstract}
The allozyme data base of Arntzen \& García-París (1995) on midwife toads (Alytes, Discoglossidae) is reanalysed considering each locus as a discrete character. The phylogeny thus inferred differs from the one obtained with genetic distances in the position of $A$. dickhilleni from the Betic region - it appears that its sister species is the widespread $A$. obstetricans, not the Mallorcan endemic $A$. muletensis. This phylogenetic hypothesis agrees with the taxonomic treatment of the genus based on morphology. A testable biogeographic hypothesis is proposed to account for the diversification of midwife toads in Iberia and the Balearics. The postulated underlying geological changes were the spread of inland saline lakes that divided Iberia (16 mY B.P.), the emergence and break-up of the Betic orogen (14 $\mathrm{mY}$ ), and the formation of the Betic Strait ( $8 \mathrm{mY})$. Dispersal over sea channels or during the Messinian Crisis $(6 \mathrm{mY})$ are deemed unlikely on the basis of ecological and biogeographical data.
\end{abstract}

\section{Resumen}

Los datos aloenzimáticos de Arntzen \& Garcia-Paris (1995) sobre sapos parteros (Alytes, Discoglossidae) se reanalizan considerando cada locus como un carácter discreto. La filogenia así inferida difiere de la obtenida a partir de distancias genéticas en la posición de $A$. dickhilleni, procedente de la región bética: todo indica que su especie hermana es el ampliamente distribuido $A$. obstetricans, y no el endemismo mallorquín A. muletensis. Esta hipótesis filogenética concuerda con el tratamiento taxonómico del género basado en la morfología. Se propone una hipótesis biogeográfica testable para explicar la diversificación de los sapos parteros en Iberia y las Baleares. Los cambios geológicos subyacentes que se postulan serían la expansión de los lagos salinos interiores que dividieron Iberia (16 $\mathrm{Ma})$, la emergencia y fracturación del orógeno bético (14 Ma) y la formación del Estrecho Bético (8 $\mathrm{Ma})$. Se considera improbable la dispersión a través de canales marinos o durante la crisis mesiniense $(6 \mathrm{Ma})$, en base a datos ecológicos y biogeográficos.

\section{Introduction}

The genus Alytes Wagler, 1830 includes the midwife toads, a well-defined group of amphibians with a geographical distribution restricted to the westernmost Palearctic. This genus has recently been the subject of a thorough study by Arntzen \& García-París (1995). These authors have gathered a large allozymic data set, which enabled them to formulate a phylogenetic and biogeographic hypothesis of diversification within Alytes. Their work is a relevant contribution to the study of biodiversity in the Mediterranean region. However, a part of their conclusions needs to be reappraised.

\section{Phylogeny}

The phylogenetic relationships among the four recognized species of Alytes are the key point. As Arntzen \& García-París (1995) show, the large genetic distances and extensive morphological differences between $A$. cisternasii Boscá, 1879 and the remaining taxa are indicative of an ancient separation. This stands against the hypothesis of a Pleistocene origin of diversity within the genus (Crespo, 1982). The pattern of cladogenesis of the other three species must conform to one of three possible trees (Fig. 1). Tree 1 in- 

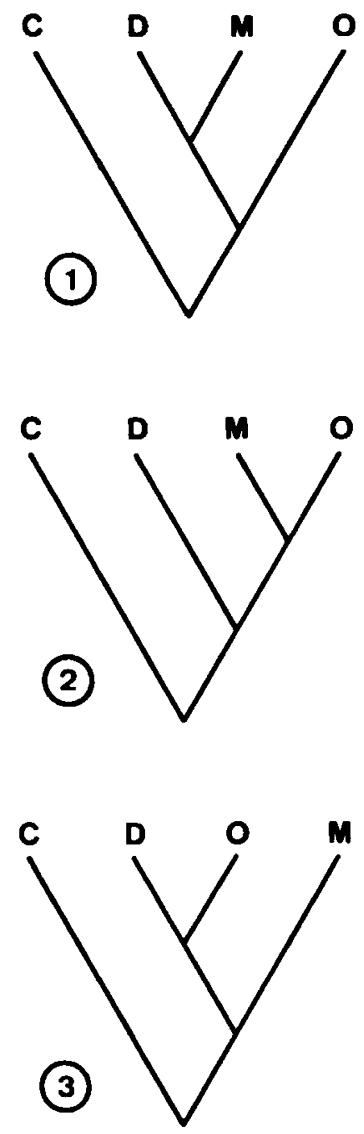

Fig. 1. The three possible trees showing the phylogenetic relationships among midwife toads. $\mathrm{C}=$ Alytes cisternasii, $\mathrm{D}=$ A. dickhilleni, $\mathrm{O}=A$. obstetricans, $\mathrm{M}=A$. muletensis.

volves a sister-group relationship between $A$. dickhilleni Arntzen \& García-París, 1995, and $A$. muletensis (Sanchíz \& Adrover, 1979), the ancestor of these two species having diverged early on from A. obstetricans (Laurenti, 1768). This tree was chosen as the correct one by Arntzen \& García-París (1995) on the basis of analyses performed with genetic distances.

The choice of Tree 1 has several drawbacks. Both in a UPGMA phenogram and in a distanceWagner tree (fig. 3 of Arntzen \& García-París, 1995), the internodal distances separating obstetricans, muletensis, and dickhilleni are quite short, suggesting that there is little support for this particular solution. Indeed, the smallest genetic distance (estimated either with 50 or 31 loci) is not between dickhilleni and muletensis, but between dickhilleni and obstetricans (Table IV of Arntzen \& García-París, 1995). Moreover, the genetic distance between dickhilleni and obstetricans is considerably less than between muletensis and $o b$ stetricans (same table). Apart from these facts, it is widely recognized that analyses based on genetic distances only cannot provide reliable estimates of phylogenetic relationships, because the rate of divergence is not necessarily the same along different lineages (Swofford \& Olsen, 1990; Huelsenbeck \& Hillis, 1993; Murphy, 1993).

In order to evaluate the different trees in Fig. 1, a cladistic analysis of the raw data has been performed. Tables II and III of Arntzen \& GarcíaParís (1995) can be recoded under the locus-ascharacter model (Murphy, 1993), as shown in Table I. This change involves considering $A$. cisternasii as the outgroup, and deleting all variation resulting from loss of alleles. This situation affects loci $A c p h-1$ and $I c d-1$ (under the independent-alleles model, the former is uninformative, and the latter favors Tree 2). A second step consists in revising conflicting loci using the functional outgroup approach. This is needed only for the Mpi- $I$ locus, and does not affect the outcome. The most parsimonious solution is Tree 3 (Table II).

The taxonomic implications of accepting Tree 3 instead of Tree 1 are important. The genus Alytes, as Arntzen \& García-París (1995) recognize, can be regarded as composed of different subgenera. After reassessing the phylogeny of the genus, the supraspecific taxa described on the basis of morphology agree with the molecular evidence. Alytes obstetricans and $A$. dickhilleni are morphologically very similar and constitute the typical subgenus Alytes (Alytes) Wagler, 1830. The Mallorcan endemic $A$. muletensis and the extinct $A$. talaioticus (Sanchíz \& Alcover, 1982) from Menorca form the taxon Alytes (Baleaphryne) Sanchíz \& Adrover, 1979. These insular species are unique in that they exhibit adaptations to rock climbing (Sanchíz \& Adrover, 1979; Sanchíz \& Alcover, 1982; Alcover et al., 1984; Arntzen \& Garcia-París, 1995). The distinctive $A$. cisternasii is the only representative of $A$. ( $\mathrm{Am}$ moryctis) Lataste, 1879 , and is adapted to bur- 
rowing in sandy soils (Crespo, 1982; Arntzen \& García-París, 1995).

\section{Biogeography}

The biogeographic hypothesis formulated to account for Tree 1 (Arntzen \& García-París, 1995) involves an unlikely series of events. In order to explain the separation of obstetricans from the ancestor of both dickhilleni and muletensis, the following steps were proposed: (a) First, the ancestor of all Alytes invaded the newly emerged Betic range in the middle Miocene. (b) The subsequent isolation of this massif caused the divergence of the populations it harboured away from the stock that remained on the continent and gave rise to cisternasii. (c) The fragmentation of the insular Betic range in the latest Miocene promoted the speciation of obstetricans on an island, separate from the ancestor of both dickhilleni and muletensis on another island. (d) During the Messinian Crisis at the end of the Miocene, the sea level of the Mediterranean dropped considerably, exposing suitable habitat that connected one of these islands to the continent, allowing the spread of obstetricans throughout most of Iberia. (e) The refilling of the Mediterranean Basin at the onset of the Pliocene caused the definitive isolation of the Balearic Islands, and thus the speciation of dickhilleni and muletensis.

This historical reconstruction has two main inconsistencies. In the first place, it is not clear how an insular species could become so successful in the mainland. No case is known of such an expansion by any Mediterranean island endemic vertebrate. Indeed, extinction after contact with continental species has invariably taken place (Alcover et al., 1981; Caloi et al., 1986). Besides, the Messinian Crisis is invoked into an ad hoc scenario: the simultaneous connection of one island to the mainland and the isolation of another island is highly speculative. Although the Messinian desiccation of the Mediterranean has been used extensively to explain all sorts of dispersal events across this sea (e.g., Agustí et al., 1984; Caloi et al., 1986; Azzaroli, 1990; Lanza \& Vanni, 1990; Sondaar et al., 1995), it remains a highly
Table I. Allozyme data recoded as presence or absence of synapomorphic character states, considering the locus as the character. The outgroup is Alytes cisternasii. Loci exhibiting no variability, loci with variation resulting from loss, and alleles present in only one species have been omitted.

\begin{tabular}{llll}
\hline Locus & dickhilleni & obstetricans & muletensis \\
\hline Acph-2 & 1 & 0 & 1 \\
Ak & 1 & 0 & 1 \\
$\alpha-G l y$ & 1 & 0 & 1 \\
Me-2 & 1 & 0 & 1 \\
Mpi-2 & 1 & 0 & 1 \\
6pgd & 1 & 0 & 1 \\
Ata-2 & 0 & 1 & 1 \\
Est-1 & 0 & 1 & 1 \\
Nadhdh-2 & 0 & 1 & 1 \\
Ata-1 & 1 & 1 & 0 \\
Ck-1 & 1 & 1 & 0 \\
GPM-1 & 1 & 1 & 0 \\
GPM-2 & 1 & 1 & 0 \\
GPM-5 & 1 & 1 & 0 \\
GPS-3 & 1 & 1 & 0 \\
Me-1 & 1 & 1 & 0 \\
Mpi-1 & 2 & 2 & 1 \\
\hline
\end{tabular}

Table II. Number of compatible characters and minimum number of steps associated with the different trees in Fig. 1.

\begin{tabular}{lll}
\hline Tree & Compatible characters & Steps \\
\hline 1 & 6 & 28 \\
2 & 3 & 31 \\
3 & 8 & 26 \\
\hline
\end{tabular}

controversial theory among geologists (Busson, 1990). Moreover, the biogeographical implications of this period appear indeed to be more modest than previously thought (Altaba, 1997a).

A more parsimonious biogeographic hypothesis can be formulated based on the reassessed phylogeny and what is known of the area's geological history (Fig. 2). The hypothesis presented below minimizes both dispersal and vicariance events, does not invoke unknown scenarios associated with the Messinian Crisis, and is in accordance with biogeographical patterns found in other taxa on the Iberian Peninsula (Altaba, 1991; 1997b).

(1) The ancestor of all Alytes had a range covering most of Iberia. The isolation of this peninsula 


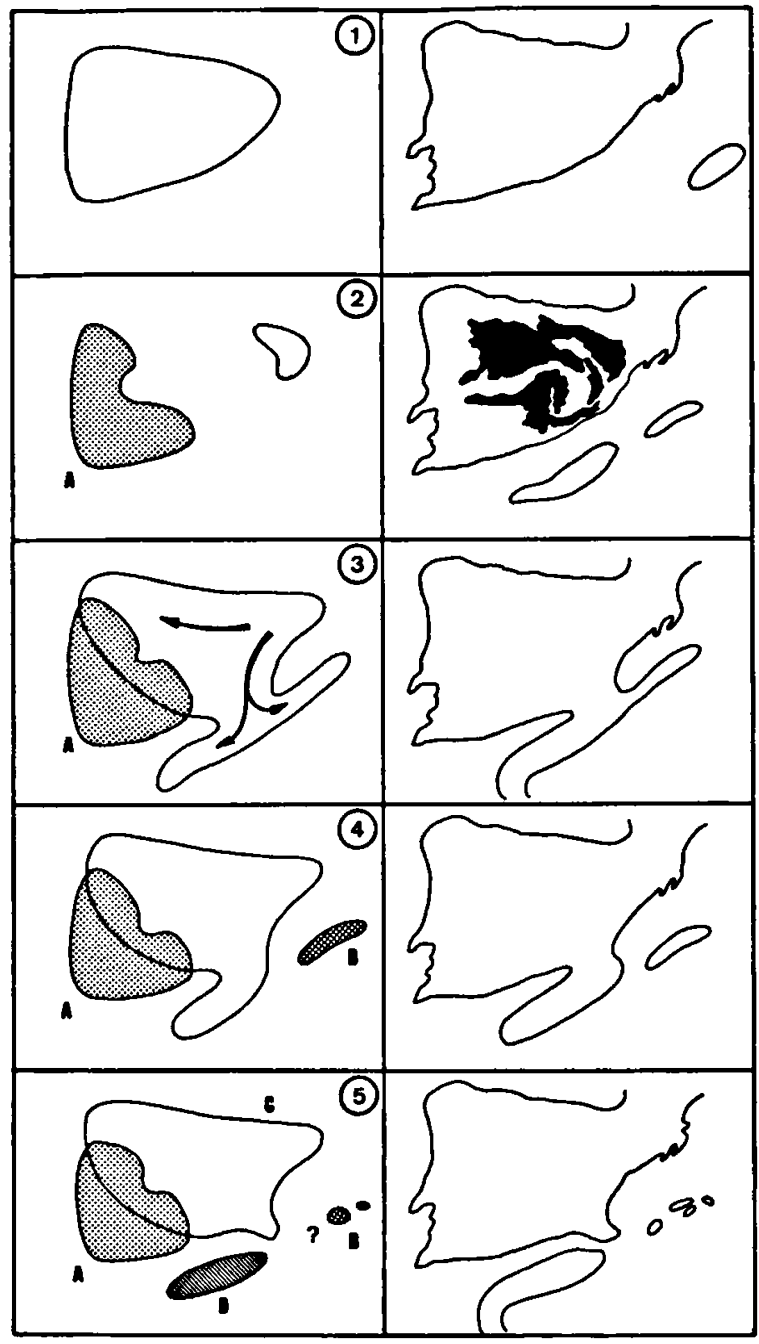

Fig. 2. Changes in the paleogeography of Iberia and the Balearics in the middle-late Miocene (right), and associated vicariance and dispersal events of Alytes (left). $\mathrm{A}=A$. (Ammoryctis) cisternasii, $\mathrm{B}=A$. (Baleaphryne), $\mathrm{C}=$ A. (Alytes) obstetricans, $\mathrm{D}=A$. (Alytes) dickhilleni. Black areas in (2) show the maximum extension of inland saline lakes. Arrows in (3) indicate active dispersal. See text for explanation.

by the recently raised Pyrenees (Muñoz, 1992) would account for the distinctness of this genus relative to other discoglossids. The current presence of midwife toads elsewhere in western Europe is most likely the result of expansion in the Pleistocene, as suggested by lack of taxonomic differentiation and reduced genetic variability in non-Iberian populations (Arntzen \& García-París, 1995).
(2) The divergence of cisternasii (stippled) from proto-obstetricans took place during the middle Langhian (ca. $16 \mathrm{mY}$ B.P.), as a consequence of the isolation caused by large inland saline lakes. These interior basins were formed in association with tectonic activity inside and along the southern and eastern edges of Iberia (Anadón et al., 1989). The maximum expansion of these lakes represented an effective barrier leading to vicariant speciation in a variety of taxa, from freshwater snails and fishes to mammals (Altaba, 1997b). The range of cisternasii never extended beyond its original area, presumably because the sandy soils in which it burrows do not exist further east. (3) The formation of the Sub-Betic Massif enabled proto-obstetricans to expand into the Betic and Balearic areas. This massif emerged during the Serravallian, at ca. $14 \mathrm{mY}$ B.P. (Weijermars, 1988; García-Cortés et al., 1991). At the onset of the Serravallian, however, crustal fracturing and extension to the south-east started at the Balearic Promontory, an area previously thrusted to the north-west as part of the Betic orogen (Fontboté et al., 1990). Thus, a temporary connection to the continent of the Balearic Promontory is likely. There is no evidence of reconnections at a later date. Although a similar land bridge has been proposed to have existed during the marine regression of the Tortonian (Bellés, 1987), the sediments of this age are clearly younger than the orogenic activity in the southern Balearic Islands (Ringheard, 1984), indicating that the extensional faulting had already formed deep troughs between the islands and the continent.

(4) The separation of the Balearic area caused the divergence of the insular group Baleaphryne. An alternative to this vicariance event is the arrival of midwife toads to the Balearic Islands across a sea strait much narrower than at present. Similar dispersal events have been proposed to account for the distribution of some amphibians on both sides of the Strait of Gibraltar (Busack, 1986; Arntzen \& Garcia-Paris, 1995). However, the physiology of amphibians and their absence from oceanic islands shows that their abilities for overseas dispersal are very limited (e.g., Alcover \& Altaba, 1995). Furthermore, vicariance between the Balearic Islands and the Sub-Betic region is 
supported by the disjunct distributions of other taxa also with limited dispersal abilities, such as land snails and cave-dwelling arthropods (Bellés, 1987; Paul \& Altaba, 1992).

(5) The most recent vicariance event was caused by the marine transgression of the Upper Tortonian (ca. $8 \mathrm{mY}$ B.P.). This enabled the reopening of the Betic Strait, a shallow channel that persisted until the late Messinian (ca. $6 \mathrm{mY}$ B.P.) connecting the Mediterranean and the Atlantic (Weijermars, 1988; Sanz de Galdeano \& Vera, 1991; Guerra-Merchán \& Serrano, 1993). This barrier isolated the southern populations and enhanced the divergence of dickhilleni from obstetricans. The continuation of tectonic activity in the Balearics caused the separation of different islands. Menorca may have been completely flooded in the Upper Tortonian (Obrador et al., 1983). Thus, the origin of the now extinct talaioticus may be in the Pleistocene, when this island was united to Mallorca during glacial stages. No Alytes are known, either alive or fossil, on the southern island of Eivissa (= Ibiza). However, no fossil sites representing aquatic or near-aquatic environments are known yet in this island (Paul \& Altaba, 1992). The absence of living midwife toads on Eivissa may be due to the mass extinction that occurred there in the middle Pleistocene, possibly due to the eruption of a nearby submarine volcano (Paul \& Altaba, 1992; Alcover et al., 1994).

\section{Recommendations for further research}

The phylogenetic and biogeographic hypothesis presented here may be contrasted along three lines of research. First, morphological investigations taking into account all species of the genus will provide additional data for further phylogenetic analyses. Second, the Moroccan Alytes should be studied in detail, as their position in the phylogeny will support or refute the postulated biogeographic events. Finally, the relationships and geographical location of fossil midwife toads will constitute a further test.

\section{Acknowledgements}

This paper benefited from comments by C. Ponsell, A. Rodriguez-Perea, J.A. Alcover, C.R.C. Paul, M. Palmer, D. Jaume, F.F.J.M. Pieters, K. Grossenbacher, and two anonymous referees.

\section{References}

Agustí, J., S. Moyà-Solà \& J. Gibert, 1984. Mammal distribution dynamics in the eastern margin of the Iberian Peninsula during the Miocene. Paléobiol. cont., 14: 33-46.

Alcover, J.A. \& C.R. Altaba, 1995. Terres isolades: les illes. In: R. Folch (ed.), Biosfera, vol. 9: Tundra $\mathrm{i}$ insularitat: 338-368 (Enciclopèdia Catalana, Barcelona).

Alcover, J.A., M. McMinn \& C.R. Altaba, 1994. Eivissa: A Pleistocene ocean-like island in the Mediterranean. Research \& Exploration, 10(2): 236-248.

Alcover, J.A., S. Moyà-Solà \& J. Pons-Moyà, 1981. Les quimeres del passat. Els vertebrats fòssils del PlioQuaternari de les Balears i Pitüses: 1-265 (Moll, Palma de Mallorca).

Alcover, J.A., E. Sanders \& B. Sanchíz, 1984. El registro fósil de los sapos parteros (Anura, Discoglossidae) de Baleares. In: H. Hemmer \& J.A. Alcover (eds.), Història biològica del ferreret: 109-121 (Moll, Palma de Mallorca).

Altaba, C.R., 1991. Phylogeny and biogeography of melanopsid snails in the Western Mediterranean region: 1-391 (Ph.D. thesis, University of Pennsylvania, Philadelphia).

Altaba, C.R., 1997a. Testing vicariance: melanopsid snails and Neogene tectonics in the Western Mediterranean. J. Biogeogr. (in press).

Altaba, C.R., 1997b. Origin and age of relict melanopsids (Gastropoda: Melanopsidae) in central Iberia. Contr. Zool., submitted.

Anadón, P., L. Cabrera \& E. Roca, 1989. Contexto estructural y paleogeográfico de los sistemas lacustres cenozoicos de España. Acta geol. hispan., 24: 167-184.

Arntzen, J.W. \& M. García-París, 1995. Morphological and allozyme studies of midwife toads (genus Alytes), including the description of two new taxa from Spain. Contr. Zool., 65: 5-34.

Azzaroli, A., 1990. Palaeogeography of terrestrial vertebrates in the perityrrhenian area. Palaeogeogr., Palaeoclimatol., Palaeoecol., 77: 83-90.

Bellés, X., 1987. Fauna cavernícola i intersticial de la Península Ibèrica i les Illes Balears: 1-207 (Moll, Palma de Mallorca).

Busack, S.D., 1986. Biogeographic analysis of the herpetofauna separated by the formation of the Strait of Gibraltar. Nat. geogr. Res., 2: 17-36.

Busson, G., 1990. Le Messinien de la Méditerranée ... vingt ans après. Géol. Fr., 3-4: 3-58.

Caloi, L., T. Kotsakis \& M.R. Palombo, 1986. La fauna a 
vertebrati terrestri del Pleistocene delle isole del Mediterraneo. Geologica romana, 25: 235-256.

Crespo, E.G., 1982. Sur la biologie évolutive des Alytes ibériques. Bull. Soc. herp. Fr., 22: 38-41.

Fontboté, J.M., J. Guimerà, E. Roca, F. Sàbat, P. Santanach \& F. Fernández-Ortigosa, 1990. The Cenozoic geodynamic evolution of the Valencia trough (Western Mediterranean). Revta. Soc. geol. España, 3: 249-259.

García-Cortés, A., H. Mansilla \& I. Quintero, 1991. Puesta de manifiesto de la Unidad Olistostrómica del Mioceno Medio, en el Sector Oriental de las Cordilleras Béticas (provincias de Jaén, Almería, Murcia y Alicante). Boln. geol. min., 102: 524-535.

Guerra-Merchán, A. \& F. Serrano, 1993. Tectosedimentary setting and chronostratigraphy of the Neogene reefs in the Almazora Corridor (Betic Cordillera, Spain). Geobios, 26: 57-67.

Huelsenbeck, J.P. \& D.M. Hillis, 1993. Success of phylogenetic methods in the four-taxon case. Syst. Biol., 42: 247-264.

Lanza, B. \& S. Vanni, 1990. Notes on the biogeography of the Mediterranean islands amphibians. Atti Conv. Lincei, 85: 335-344.

Muñoz, J.A., 1992. Evolution of a continental collision belt: ECORS-Pyrenees crustal balanced cross-section. In: K.R. McClay (ed.), Thrust tectonics: 235-247 (Chapman \& Hall, London).

Murphy, R.W., 1993. The phylogenetic analysis of allozyme data: invalidity of coding alleles by presence/absence and recommended procedures. Biochem. Syst. Ecol., 21: 2538.
Obrador, A., L. Pomar, A. Rodríguez-Perea \& M.J. Jurado, 1983. Unidades deposicionales del neógeno menorquín. Acta geol. hispan., 18: 87-97.

Paul, C.R.C. \& C.R. Altaba, 1992. Els mol-luscs terrestres fòssils de les Illes Pitiüses. Boll. Soc. Hist. nat. Balears, 34: 141-170.

Ringheard, Y., 1984. The geological history of Eivissa and Formentera. In: H. Kuhbier, J.A. Alcover \& C. Guerau D'Arellano (eds.), Biogeography and ecology of the Pityusic islands: 25-104 (Dr. W. Junk, The Hague).

Sanchíz, F.B. \& R. Adrover, 1979. Anfibios fósiles del Pleistoceno de Mallorca. Doñana, Acta Vertebrata, 4: 525.

Sanchíz, F.B. \& J.A. Alcover, 1982. Un nou discoglòssid (Amphibia: Anura) de l'Holocè de Menorca. Butll. Inst. catal. Hist. nat., (Sec. geol., 3) 48: 99-105.

Sanz de Galdeano, C. \& J.A. Vera, 1991. Una propuesta de clasificación de las cuencas neógenas béticas. Acta geol. hispan., 26: 205-227.

Sondaar, P.Y., M. McMinn, B. Seguí \& J.A. Alcover, 1995. Paleontological interest of karstic deposits from the Gymnesic and Pityusic islands. Endins, 20: 155-170.

Swofford, D.L. \& G.J. Olsen, 1990. Phylogeny reconstruction. In: D.M. Hillis \& C. Moritz (eds.), Molecular systematics: 411-501 (Sinauer, Sunderland, Massachusetts).

Weijermars, R., 1988. Neogene tectonics in the Western Mediterranean may have caused the Messinian Salinity Crisis and an associated glacial event. Tectonophysics, 148: 211-219.

Received: 6 February 1996 